\section{Determining the Flowering Requirements of Two Aquilegia Cultivars}

\author{
Catherine M. Whitman and Erik S. Runkle ${ }^{1}$ \\ Department of Horticulture, Michigan State University, 1066 Bogue Street, \\ Room A288, East Lansing, MI 48824-1325

\begin{abstract}
Additional index words. Columbine, herbaceous perennial, juvenility, photoperiod
\end{abstract} \\ vernalization
}

\begin{abstract}
Flowering of the herbaceous perennial Aquilegia is generally considered to require vernalization after seedlings are mature, whereas photoperiod has little or no effect. We performed experiments to determine the flowering responses for two Aquilegia $\times$ hybrida varieties, one of which reportedly has reduced cold requirements. Seedlings of Aquilegia 'Origami Blue and White' and 'Winky Double Red and White' with three to five leaves were either placed directly into a $5^{\circ} \mathrm{C}$ cooler with low-intensity lighting for 9 hours/ day or transplanted to $13-\mathrm{cm}$ containers and grown (bulked) for 0,3 , or 6 weeks at $20^{\circ} \mathrm{C}$ under 9-hour short days (SDs) or 16-h long days (LDs). Plants were then cooled at $5{ }^{\circ} \mathrm{C}$ for 0,5 , or 10 weeks and placed in a common forcing environment at $20^{\circ} \mathrm{C}$ under $\mathrm{LDs}$. Flowering response of the two cultivars differed markedly. All Aquilegia 'Origami Blue and White' plants placed directly into the forcing environment flowered and in a mean of 93 days. Flowering percentage of plants cooled in the plug tray decreased with increasing duration of cold treatment, and only $15 \%$ flowered after a 10 -week cold treatment. All plants bulked for 3 or 6 weeks before cold treatment flowered after 25 to 36 days in the forcing environment. Adding bulking and forcing time together, time to flowering of 'Origami Blue and White' was complete and most rapid (62 days) when plants were bulked for 3 weeks under SDs and then forced under LDs. In contrast, no 'Winky Double Red and White' plants flowered without cold treatment, and 6 weeks of bulking followed by 10 weeks of cold was required for $100 \%$ flowering. These results indicate that 'Origami Blue and White' has a relatively short juvenile phase and flowering was promoted by SD bulking or cold treatment, whereas 'Winky Double Red and White' has a longer juvenile phase and requires cold for flowering.
\end{abstract}

Plants respond to environmental cues such as temperature and photoperiod to flower when reproductive success is most likely. Producers and retailers of flowering plants require them to bloom for specific, predetermined dates when they can be marketed most successfully. Ornamental herbaceous perennials have posed some unique challenges to growers attempting to produce uniform crops in flower consistently. This has prompted research into the flowering requirements of a wide range of herbaceous perennials, revealing that vernalization and photoperiod can induce or hasten flowering and that seedlings of several species must complete a juvenile phase before they can respond to inductive conditions (Runkle et al., 2001).

Aquilegia includes $\approx 65$ species, and extensive hybridization has yielded many cultivars of this popular spring-blooming perennial

Received for publication 12 Mar. 2012. Accepted for publication 13 July 2012.

We gratefully acknowledge funding by horticulture companies supportive of Michigan State University floricultural research and the support of Michigan State University's AgBioResearch. We also thank David Joeright and Mike Olrich for their greenhouse assistance.

${ }^{1}$ To whom reprint requests should be addressed; e-mail runkleer@msu.edu.
(Armitage, 1997; Whitman et al., 2003a). Vernalization is a cold treatment that induces or promotes flowering (Chouard, 1960) and flowering of Aquilegia is generally considrequirement varies among cultivars (Finical, 1998; Weiler and Shedron, 1986; Whitman et al., 2003a, 2003b). No nonvernalized seedlings of 'McKana's Giant', 'Fairyland', or 'Crimson Star' flowered within 7 months after sowing (Shedron and Weiler, 1982). Six weeks of cold was the minimum needed for complete flowering of populations of 'Bluebird', 'Cardinal', 'Dove', 'Miniblue', and 'Robin' (White et al., 1989). However, 50\% of nonvernalized 'McKana's Giant' seedlings flowered after 11 to 12 months in the greenhouse (Shedron and Weiler, 1982). In separate studies, all noncooled $A$. flabellata 'Cameo Blue and White' seedlings flowered an average of $38 \mathrm{~d}$ after transplant (Finical, 1998 ) and $90 \%$ of noncooled 'Remembrance' flowered, although time to flower was not presented (Niu et al., 2002). Although some nonvernalized plants bloom, vernalization often significantly hastens flowering as reported in four cultivars of A. flabellata and four interspecific hybrid cultivars (Garner and Armitage, 1998), five selections of Aquilegia (Finical, 1998), and 'McKana's Giant' (Shedron and Weiler, 1982). ered to require vernalization, although this
Vernalization is effective when Aquilegia seedlings have passed the juvenile stage, which occurred at 12 to 15 leaves in 'McKana's Giant', 'Fairyland', and 'Crimson Star' (Shedron and Weiler, 1982) and selected hybrids in the 'Swan', 'Music', and 'Songbird' series (Whitman et al., 2003b). Once plants were mature, the vernalization requirement varied among cultivars and was reported as 10,4, and 8 weeks for 'McKana's Giant', 'Fairyland', and 'Crimson Star', respectively (Shedron and Weiler, 1982). Cultivars in the 'Swan' series flowered after only 3 weeks of cold (Whitman et al., 2003b). After vernalization, photoperiod has little or no effect on flowering of Aquilegia (Shedron and Weiler, 1982; Weiler and Shedron, 1986). To simplify production and improve performance in warmer climates, plant breeders have developed Aquilegia cultivars with reduced vernalization requirements (Merritt et al., 1997). In 2002, the Aquilegia 'Origami' series was released (Thomas and White, 2002) with a reported vernalization requirement of 14 to $21 \mathrm{~d}$ at 5 to $10{ }^{\circ} \mathrm{C}$ (Syngenta Flowers, n.d.). Kieft-Pro-Seeds developed 'Winky Double Red and White' (Burns et al., 2003); however, little information on flowering requirements was available. Our objective was to test these cultivars for juvenility and vernalization responses so that populations of plants could be commercially produced in flower in a complete and predictable manner.

\section{Materials and Methods}

Seedlings of Aquilegia $\times$ hybrida 'Origami Blue and White' and 'Winky Double Red and White' in 128-cell plug trays $(10-\mathrm{mL}$ cell volume) were provided by a wholesale plug producer (C. Raker \& Son, Litchfield, MI). Plugs of both varieties were received on 6 Dec. 2001 for Year 1; in Year 2, 'Origami Blue and White' were received on 19 Dec. 2002 and 'Winky Double Red and White' were received 7 Jan. 2003. Seedlings were $\approx 9$ weeks old when received and had average node counts of four or five for 'Origami Blue and White' and three to five for 'Winky Double Red and White'.

In this study, we define bulking as a period during which plants are allowed to increase in size to complete the juvenile phase, and no attempt is made to induce flowering. The seedlings were exposed to bulking treatments followed by cold treatments and then were forced in a common environment. For bulking treatments, plugs were transplanted to $13-\mathrm{cm}(1.1-\mathrm{L})$ square containers filled with a commercial peat-perlite media (Sure-Mix; Michigan Grower Products, Galesburg, MI) and placed in a glass greenhouse with a constant set point of $20^{\circ} \mathrm{C}$ under either 9-h SDs or 16-h LDs. The 9-h bulking photoperiods were created by opening and closing black cloth at 0800 and $1700 \mathrm{HR}$, respectively. The 16-h bulking photoperiods were created by extending 9-h photoperiods with incandescent lighting under the black cloth, providing 1 to $3 \mu \mathrm{mol} \cdot \mathrm{m}^{-2} \cdot \mathrm{s}^{-1}$ at canopy level from $1700 \mathrm{HR}$ to $2400 \mathrm{HR}$. Ten plants per treatment (except for 
seven plants per treatment in Year 2 for 'Winky Double Red and White') were bulked for 0,3 , or 6 weeks. Seedlings in nonbulked treatments were cooled in plug trays and transplanted after vernalization. In all greenhouse areas, from 0600 to $2200 \mathrm{HR}$, high-pressure sodium lamps provided a supplemental photosynthetic photon flux (PPF) of 40 to $50 \mu \mathrm{mol} \cdot \mathrm{m}^{-2} \cdot \mathrm{s}^{-1}$ at the canopy level when the ambient greenhouse $P P F$ was less than $200 \mu \mathrm{mol} \cdot \mathrm{m}^{-2} \cdot \mathrm{s}^{-1}$ and were shut off when the ambient $P P F$ was greater than $400 \mu \mathrm{mol} \cdot \mathrm{m}^{-2} \cdot \mathrm{s}^{-1}$.

After bulking, plants received cold treatments for 0,5 , or 10 weeks in a $5 \pm 0.5{ }^{\circ} \mathrm{C}$ refrigerated chamber that was illuminated for $9 \mathrm{~h} \cdot \mathrm{d}^{-1}$ with cool-white fluorescent lamps (VHOF96T12; Philips, Bloomfield, NJ) at $10 \mu \mathrm{mol} \cdot \mathrm{m}^{-2} \cdot \mathrm{s}^{-1}$. After bulking and cold treatments, plants were placed in a common greenhouse forcing environment with a constant set point of $20{ }^{\circ} \mathrm{C}$ under 16 -h photoperiods provided with high-pressure sodium lamps from 0600 to $2200 \mathrm{HR}$. Seedlings in the nonbulked and noncooled treatment were transplanted on arrival and placed immediately in the forcing environment. In Year 2, two additional treatments were added: 'Origami Blue and White' plants (10 per treatment) were transplanted and maintained under 9- or 16-h bulking photoperiods for the course of the experiment.

Air temperatures on each bench were monitored with two 36-gauge $(0.127-\mathrm{mm})$ thermocouples connected to a CR10 data logger (Campbell Scientific, Logan, UT). The data logger collected temperature data every $10 \mathrm{~s}$ and recorded the hourly average. To provide uniform night temperatures, the data logger controlled a $1500-\mathrm{W}$ electric heater under each bench, which provided supplemental heat as needed throughout the night. The maximum difference in average daily air temperature between any two bulking treatments was $0.7^{\circ} \mathrm{C}$ for both years (data not shown). Average daily air temperatures in the forcing environment during the experiments were $21.2{ }^{\circ} \mathrm{C}$ (Year 1) and $20.6{ }^{\circ} \mathrm{C}$ (Year 2).

Average photosynthetic daily light integral (DLI) was measured at the canopy level with LI-COR quantum sensors (Model LI189; LI-COR, Lincoln, NE) connected to a CR10 data logger (Campbell Scientific). Plants in bulking treatments (9-h SD or 16-h LD provided with incandescent lamps) received 8 to $10 \mathrm{~mol} \cdot \mathrm{m}^{-2} \cdot \mathrm{d}^{-1}$ during Year 1 and 6 to $8 \mathrm{~mol} \cdot \mathrm{m}^{-2} \cdot \mathrm{d}^{-1}$ during Year 2 . Average DLI in the forcing environment (16-h LD provided with high-pressure sodium lamps) was $15 \mathrm{~mol} \cdot \mathrm{m}^{-2} \cdot \mathrm{d}^{-1}$ in both years.

In Year 1, plants were fertilized at every irrigation with well water (electrical conductivity of $0.70 \mathrm{mS} \cdot \mathrm{cm}^{-1}$ and $105 \mathrm{mg}$ calcium (Ca), $35 \mathrm{mg}$ magnesium, and $85 \mathrm{mg}$ sulfur/L) acidified with $\mathrm{H}_{2} \mathrm{SO}_{4}$ to a titratable alkalinity of $130 \mathrm{mg} \mathrm{CaCO}_{3} / \mathrm{L}$ and water-soluble fertilizer providing $\left(\mathrm{mg} \cdot \mathrm{L}^{-1}\right)$ : $125 \mathrm{~N}-12 \mathrm{P}-125 \mathrm{~K}-$ $13 \mathrm{Ca}(30 \%$ ammoniacal $\mathrm{N})$ plus $1.0 \mathrm{Fe}-0.5$ $\mathrm{Mn}-0.5 \mathrm{Zn}-0.5 \mathrm{Cu}-0.1 \mathrm{~B}-0.1 \mathrm{Mo} \mathrm{mg} \cdot \mathrm{L}^{-1}$ (MSU Special; Greencare Fertilizers, Chicago, IL). In Year 2, plants were irrigated as necessary with reverse-osmosis water supplemented with water-soluble fertilizer to provide the following $\left(\mathrm{mg} \cdot \mathrm{L}^{-1}\right): 125 \mathrm{~N}-12 \mathrm{P}-$ $100 \mathrm{~K}-65 \mathrm{Ca}-12 \mathrm{Mg}-1.0 \mathrm{Fe}$ and $\mathrm{Cu}-0.5 \mathrm{Mn}$ and $\mathrm{Zn}-0.3 \mathrm{~B}$, and $0.1 \mathrm{Mo}$.

Vegetative node numbers were counted at the beginning (both years) and end (Year 2 only) of bulking, and dates of first open flower were recorded. At first open flower, number of nodes and flower buds and plant height were recorded. Data for days to flower, node number, flower bud number, and height for Years 1 and 2 were subjected to analysis of variance, PROC MIXED, and Duncan's mean separation with SAS (SAS Institute, Inc., Cary, NC).

\section{Results}

'Origami Blue and White'. All plants flowered in all treatments with the exception of nonbulked plants cooled in the plug tray (Fig. 1A). Flowering percentage of plants cooled as plugs decreased with increasing duration of cold treatment, and only $10 \%$ or $20 \%$ flowered after the 10 -week cold treatment in Year 1 or Year 2, respectively (data not shown). The nonflowering plants were healthy and vigorous and continued to grow until they were discarded 15 weeks after placement in the forcing environment.

Seedlings transplanted and grown under constant 9- or 16-h bulking photoperiods had seven to 10 nodes after 3 weeks and 12 to 18 nodes after 6 weeks and were similar under both photoperiods (data not shown). These noncooled seedlings and those placed directly in the forcing environment flowered 86 to $97 \mathrm{~d}$ after transplant (Fig. 2A-B). Those remaining in the bulking treatments flowered significantly sooner (10 or $11 \mathrm{~d}$ ) than those placed directly in the forcing environment (Fig. 2B). Plants cooled as plugs for 5 or 10 weeks flowered more quickly in Year 2 (54 or $32 \mathrm{~d}$ ) than in Year 1 (112 or $100 \mathrm{~d})$.
Plants bulked for 3 weeks under SDs (no cold treatment) flowered $26 \mathrm{~d}$ sooner than those bulked under LDs in both years. However, time to flower after 6 weeks of bulking was similar whether plants were bulked under SDs or LDs. Plants in all treatments that included both bulking and cold flowered 25 to $36 \mathrm{~d}$ after cold treatments ended in both years. Compared with noncooled plants, 10 weeks of cold hastened flowering in most cases. Flowering time for bulked seedlings was similar whether plants were cooled for 5 or 10 weeks.

Plants that had been bulked and vernalized formed the same number of nodes $(\approx 10)$ before flowering during forcing (Fig. 2C-D). In contrast, plants that were cooled as plugs, those that were grown under constant 9- or 16-h photoperiods, and noncooled plants bulked under LDs for 3 weeks formed significantly more nodes beneath the first flower. Bulking and cold treatments had little effect on flower bud number in Year 1, which averaged between 16 and 29 buds per plant (Fig. 2E). In Year 2, plants that remained under 9-h SDs and those cooled as plugs for 10 weeks formed 10 or less flower buds each (Fig. 2F). Bud number in all other treatments was between 22 and 43. The greatest numbers of buds were formed when plants were continually in the forcing environment, bulked under LD for 3 weeks (no cold), or bulked for 6 weeks under LD. Bulked plants formed similar numbers of buds whether they were cooled for 5 or 10 weeks.

Plant height in Year 1 was between 31 and $50 \mathrm{~cm}$ (Fig. 2G) and bulking and cold treatments had little effect on height. In Year 2, plants that remained under the 9-h photoperiod were $\approx 12 \mathrm{~cm}$ tall at flower (Fig. 2H). Plants in all other treatments were 32 to $56 \mathrm{~cm}$ in height. Noncooled plants were taller at flower if bulked under LDs than under SDs.
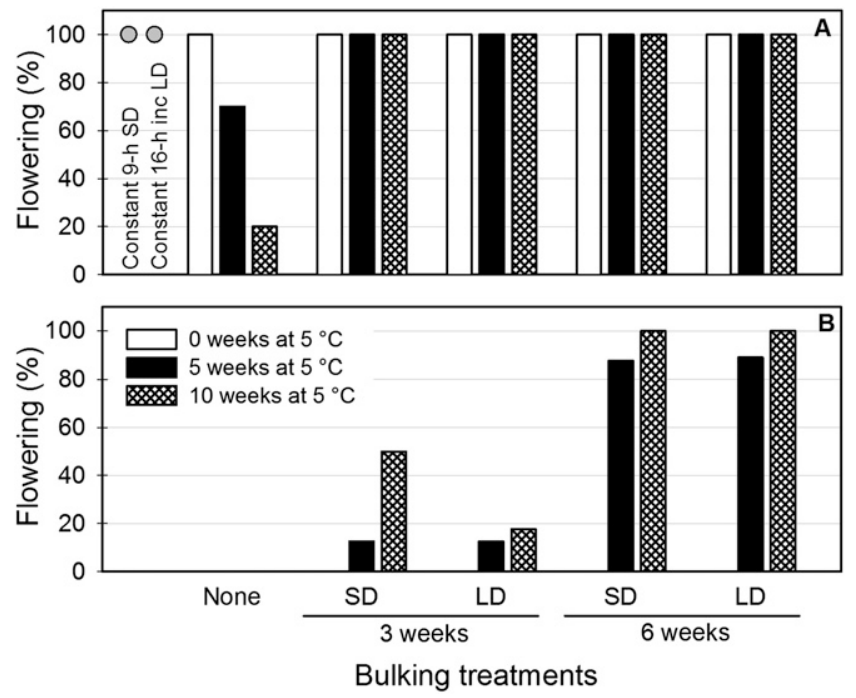

Fig. 1. Flowering percentages of Aquilegia 'Origami Blue and White' (A) and 'Winky Double Red and White' (B) after different bulking and low-temperature treatments. Seedlings were bulked under 9-h short days (SDs) or 16-h long days (LDs) provided with incandescent (inc) lamps and then vernalized at $5{ }^{\circ} \mathrm{C}$. Plants were subsequently forced under 16 -h LDs provided with high-pressure sodium lamps. 


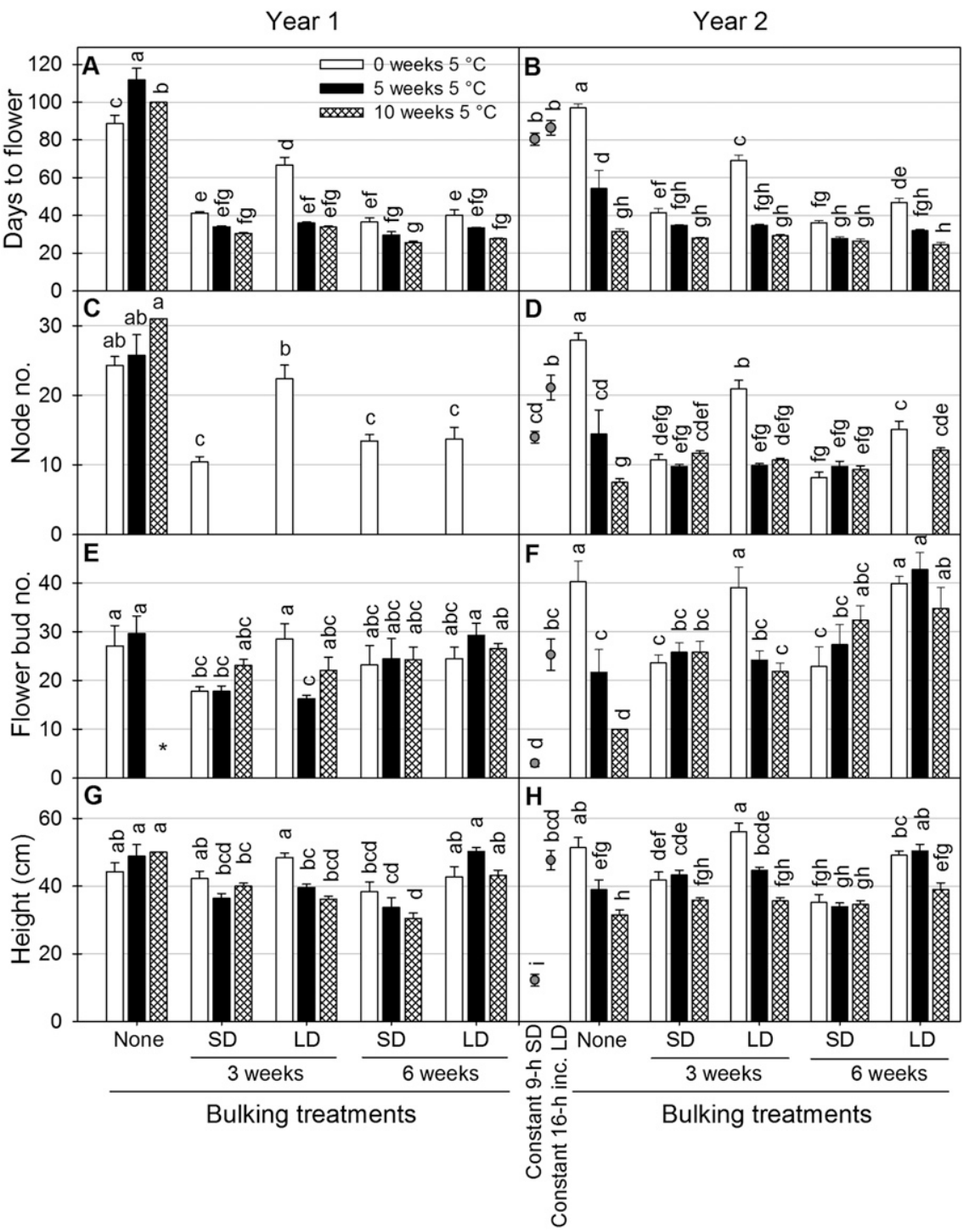

Fig. 2. (A-H) Flowering responses of Aquilegia 'Origami Blue and White' to bulking under 9-h short days (SDs) or 16-h long days (LDs) provided with incandescent (inc) lamps followed by vernalization for 0 , 5 , or 10 weeks at $5{ }^{\circ} \mathrm{C}$. Plants were subsequently forced under LDs provided by high-pressure sodium lamps; those in the nonbulked, noncooled treatment were in the forcing environment throughout the experiment. Vertical bars represent sEs. Means with the same letter are not significantly different at $P \geq$ 0.05 . *Missing data.

'Winky Double Red and White'. No plants flowered without bulking and a cold treatment (Fig. 1B). Plants had six to eight leaves after 3 weeks of bulking and eight to 13 leaves after 6 weeks of bulking regardless of photoperiod (data not shown). 'Winky Double Red and White' required 6 weeks of bulking followed by 10 (Year 1) or 5 or more (Year 2) weeks of cold to achieve $100 \%$ flowering (data not shown). Flowering was most rapid ( 22 to $32 \mathrm{~d}$ in the forcing environment; Fig. 3A-B) in plants bulked under either SDs or LDs and then cooled for 10 weeks before forcing. Photoperiod during bulking had little effect on time to flower.

Plants formed between seven and 11 nodes beneath the first flower during forcing (Fig. 3C). Surprisingly, plants that had been bulked for 6 weeks generally formed more nodes before flowering than those bulked for 3 weeks. Flower bud number both years was unaffected by bulking photoperiod or bulking duration and was similar whether plants were cooled for 5 or 10 weeks (Fig. 3D). Flower bud number averaged between 19 and 32 per plant, and the greatest number formed on plants bulked for 6 weeks under LDs and then cooled for 5 weeks. Plants were 27 to $34 \mathrm{~cm}$ tall at flower both years (Fig. 3E).

\section{Discussion}

All noncooled 'Origami Blue and White' plants flowered, indicating that they do not require exposure to low temperatures for flowering. Complete flowering without vernalization was reported in A. flabellata 'Cameo Blue and White' (Finical, 1998), whereas there were conflicting results about the absolute vernalization requirements for 'Bluebird' and 'Dove' (Finical, 1998; White et al., 1990a, 1990b; Zhang et al., 1991). Adding bulking and forcing time together, time to flowering of 'Origami Blue and White' was most rapid $(\approx 62 \mathrm{~d})$ when plants were bulked for 3 weeks under SDs and then forced under LDs. Total bulking and forcing time of plants exposed to only LDs during Year 1 or Year 2, respectively, was 89 or $97 \mathrm{~d}$ (no bulking; constant 16-h from high-pressure sodium lamps), 87 or $90 \mathrm{~d}$ ( 3 weeks of bulking), or 82 or $89 \mathrm{~d}$ (6 weeks of bulking).

In some species, vernalization can be at least partially substituted by SDs. SDs can substitute for cold in the biennial Campanula medium (Wellensiek, 1985), one strain of Scabiosa succisa (Chouard, 1960), some cultivars of Coreopsis $\times$ grandiflora (Ketellapper and Barbaro, 1966; Padhye, 2006), and many temperate perennial grasses (Heide, 1994). The vernalization response in winter wheat can be replaced by interrupting LDs with 6 weeks of SDs, and SDs influence expression of vernalization genes (Dubcovsky et al., 2006). In Aquilegia 'Origami Blue and White', 3 weeks of SDs reduced time to flower in the forcing environment from $\approx 93$ to $\approx 41 \mathrm{~d}$, and the node number increase during forcing was reduced from $\approx 26$ to $\approx 11$. Extending the $\mathrm{SD}$ duration to 6 weeks had no effect on any of the flowering parameters measured. Therefore, exposure to SDs chronologically and developmentally hastened flowering of 'Origami Blue and White'.

Plants were under two different constant LD treatments in Year 2. Those under LD provided with incandescent lamps flowered significantly (10 d) sooner than those under LD provided with high-pressure sodium lamps and formed fewer nodes before flowering (21 vs. 28). Light quality during the day extension differed between the two treatments and may have influenced flower induction. Previous studies suggest an interaction between plant age and light source. When nonvernalized Aquilegia plants were moved from a greenhouse to a growth chamber with coolwhite fluorescent lighting at the four- or fiveleaf stage, none flowered (White et al., 1990b) but when plants were moved to the growth chamber at the 12- to 14-leaf stage, they initiated buds 5.5 months after sowing (White et al., 1990a).

Surprisingly, flowering of nonbulked 'Origami Blue and White' seedlings was suppressed by cold treatment; flowering percentage and flower bud number generally decreased as cold treatment duration increased. We have no explanation for this because plants remained vigorous and grew vegetatively in the forcing environment in both years. In contrast, none of the noncooled 'Winky Double Red and White' flowered regardless of bulking treatment, which is consistent with most other varieties of Aquilegia studied (Finical, 1998; Shedron and Weiler, 1982; Weiler and Shedron, 1986; Whitman et al., 2003a, 2003b).

'Winky Double Red and White' plants that were not bulked and cooled had three to five leaves, and because none flowered, seedlings were still juvenile. After 3 weeks of bulking, plants had six to eight leaves but 


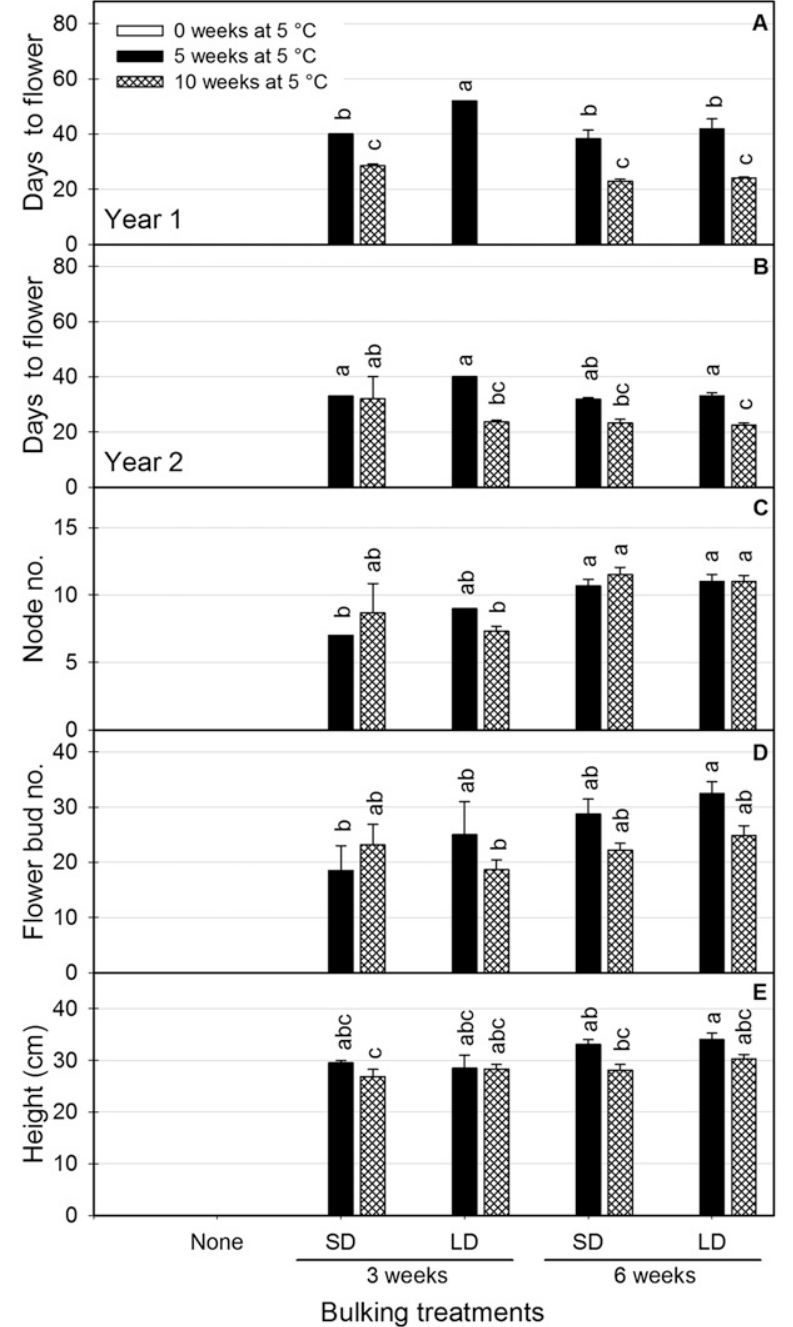

Fig. 3. (A-E) Flowering responses of Aquilegia 'Winky Double Red and White' to bulking under 9-h short days (SDs) or 16-h long days (LDs) provided with incandescent lamps followed by vernalization at $5{ }^{\circ} \mathrm{C}$ for 0,5 , or 10 weeks. Plants were subsequently forced under LDs provided with high-pressure sodium lamps. Means in $\mathbf{C}$ are from Year 2, whereas means in $\mathbf{D}$ and $\mathbf{E}$ are from both replications. Vertical bars represent SES. Means with the same letter are not significantly different at $P \geq 0.05$.

only some plants subsequently flowered after cold treatments. Similarly, seedlings of 'McKana's Giant', 'Fairyland', and 'Crimson Star' with six to eight leaves did not flower after cold treatments (Shedron and Weiler, 1982). However, once 'Winky Double Red and White' plants had eight to 13 leaves, all plants were mature because all plants flowered after a 10 -week cold treatment. Minimum node number for complete flowering was 10 for 'Cameo' and 'Crimson Star'; 11 to 14 for 'Bluebird' and 'Musik White'; 12 to 15 for 'McKana's Giant', 'Fairyland', and 'Crimson Star'; and greater than 12 for 'Bluejay' (Finical, 1998; Shedron and Weiler, 1982). However, results from two separate experiments by Finical (1998) showed that plants had to be bulked in larger containers, not in small plugs, for complete flowering of most cultivars studied.

For complete flowering and the most rapid commercial production of these two Aquilegia varieties, both cultivars should be bulked under SDs. Once 'Origami Blue and
White' plants have seven to 10 nodes, they can be transferred to LDs for subsequent flowering without a cold treatment. 'Winky Double Red and White' should be bulked until plants have at least eight to 13 nodes, cooled at $5{ }^{\circ} \mathrm{C}$ for 10 weeks, and then forced under LDs. According to results from other published studies, we expect that most other Aquilegia cultivars would flower if the protocol for 'Winky Double Red and White' is followed.

\section{Literature Cited}

Armitage, A. 1997. Herbaceous perennial plants. Stipes Publishing, Champaign, IL.

Burns, C., C. Evans, and B. White. 2003. Pick of the pack trials, part II. Greenhouse Product News 13(7):52-69.

Chouard, P. 1960. Vernalization and its relations to dormancy. Annu. Rev. Plant Physiol. 11:191238.

Dubcovsky, J., A. Loukoianov, D. Fu, M. Valarik, A. Sanchez, and L. Yan. 2006. Effect of photoperiod on the regulation of wheat vernalization genes VRN1 and VRN2. Plant Mol. Biol. 60:469-480

Finical, L.M. 1998. The effects of plant age, photoperiod, vernalization, and temperature on the growth and development of Aquilegia and Gaura. MS thesis, Dept. of Horticulture, Michigan State Univ., East Lansing, MI.

Garner, J.M. and A. Armitage. 1998. Influence of cooling and photoperiod on growth and flowering of Aquilegia L. cultivars. Sci. Hort. 75:8390.

Heide, O.M. 1994. Control of flowering and reproduction in temperate grasses. New Phytol. 128:347-362.

Ketellapper, H.J. and A. Barbaro. 1966. The role of photoperiod, vernalization and gibberellic acid in floral induction in Coreopsis grandiflora Nutt. Phyton 23:33-41.

Merritt, R.H., T. Gianfagna, R.T. Perkins, III, and J.R. Trout. 1997. Growth and development of aquilegia in relation to temperature, photoperiod and dry seed vernalization. Sci. Hort. 69:99-106.

Niu, G., R. Heins, A. Cameron, and W. Carlson. 2002. Prevernalization daily light integral and vernalization temperature influences flowering of herbaceous perennials. HortScience 37:10281031.

Padhye, S.R. 2006. The influence of vernalization on flowering of Campanula 'Birch Hybrid' and Dianthus gratianopolitanus 'Bath's Pink' and the regulation of flowering of Coreopsis grandiflora 'Sunray' by vernalization, photoperiod and light quantity. PhD diss., Dept. of Horticulture, Michigan State Univ., East Lansing, MI.

Runkle, E., R. Heins, A. Cameron, and W. Carlson. 2001. Horticultural flowering of herbaceous perennials. Flowering Newsletter 31:34-43.

Shedron, K.G. and T.C. Weiler. 1982. Regulation of growth and flowering in Aquilegia $\times$ hybrida Sims. J. Amer. Soc. Hort. Sci. 107:878-882.

Syngenta Flowers. (n.d.) Aquilegia Origami ${ }^{\mathrm{TM}} .17$ Feb. 2012. <http://www.syngentaflowers.com/ country/us/en/seeds/GrowingGuidelinesLib/ aquilegia.pdf $>$.

Thomas, B.D. and B. White. 2002. New at the pack trials. Greenhouse Product News 12(7): $48-55$.

Weiler, T.C. and K.G. Shedron. 1986. Aquilegia $\times$ hybrida, p. 18-21. In: Halevy, A.H. (ed.). Handbook of flowering. Vol. V. CRC Press, Boca Raton, FL.

Wellensiek, S.J. 1985. Campanula medium, p. 123-126. In: Halevy, A.H. (ed.). Handbook of flowering. Vol. II. CRC Press, Boca Raton, FL. White, J.W., D.J. Beattie, and E.J. Holcomb. 1989. Flowering studies with Aquilegia cultivars. Acta Hort. 252:219-226.

White, J.W., H. Chen, and D.J. Beattie. 1990a. Gibberellin, light, and low-temperature effects on flowering of Aquilegia. HortScience 25: $1422-1424$.

White, J.W., H. Chen, X. Zhang, D.J. Beattie, and H. Grossman. 1990b. Floral initiation and development in Aquilegia. HortScience 25:294 296.

Whitman, C., A. Cameron, E. Runkle, and R. Heins. 2003a. Herbaceous perennials: Aquilegia (columbine). Greenhouse Grower 21(12): 80-86.

Whitman, C., A. Cameron, E. Runkle, and R. Heins. 2003b. Herbaceous perennials: Aquilegia tables. Greenhouse Grower 21(14):60.

Zhang, X., J.W. White, and D.J. Beattie. 1991. Regulation of flowering in Aquilegia. J. Amer. Soc. Hort. Sci. 116:792-797. 